\title{
BESIMOKANTI ORGANIZACIJA ŠIUOLAIKINIO VIEŠOJO VALDYMO KONTEKSTE
}

\author{
Laima Skrickienė $\dot{e}^{1,2}$, Daiva Čepuraite் ${ }^{1,2}$, Kęstutis Štaras ${ }^{1,2,3}$ \\ ${ }^{1}$ Mykolo Romerio universitetas, ${ }^{2}$ Všl Centro poliklinika, \\ ${ }^{3}$ Vilniaus universiteto Medicinos fakultetas
}

Raktažodžiai: Besimokanti organizacija, mokymasis, šiuolaikinis viešasis valdymas, pokyčių valdymas.

\begin{abstract}
Santrauka
Vertinant Besimokančios organizacijos bruožų raišką šiuolaikinio viešojo valdymo kontekste ir remiantis Karen E. Watkins ir Victoria J. Marsick sudarytu klausimynu [30], $2017 \mathrm{~m}$. sausio - kovo mèn. atliktas tyrimas viešojoje ambulatorinejje asmens sveikatos priežiūros įstaigoje, apklausti 228 darbuotojai. Daugelyje viešojo sektoriaus organizacijų veiklos vadyba, vertinimas ir rezultatų analize tampa vis svarbesne viešojo sektoriaus institucijų veiklos sudedamaja dalimi. Viešojo sektoriaus organizacijoms, siekiančioms ịgyvendinti Besimokančios organizacijos koncepciją, reikia pertvarkyti savo organizacijos valdymo struktūrą. Ambulatorinès asmens sveikatos priežiūros įstaigos kritinis darbuotojų mokymosi taškas yra nepakankamas finansinès ir kitos pagalbos skyrimas visų pareigybių specialistams. Atlikto tyrimo metu nustatyta, kad aukščiausiai ịvertintas mokymasis organizaciniame lygmenyje, toliau - grupiu/ komandų, žemiausiai - individualiame lygmenyje. Galime teigti, kad tyrime dalyvavusios ambulatorinès asmens sveikatos priežiūros įstaigos kryptingas organizacinis mokymasis sąlygoja tobulèjimą, didina konkurencini pranašumą ir leidžia prisitaikyti prie pokyčių bei juos valdyti, o kiekvienam jos darbuotojui suteikiama savirealizacijos galimybè. Tyrimo metu nustatyta, kad didžiausios ambulatorinès asmens sveikatos priežiūros organizacijos stiprybès: dèmesio kreipimas ị kliento (paciento) nuomonę; organizacija suteikia darbuotojams priemones, reikalingas darbui atlikti; darbuotojai geba dirbti komandoje, padeda vieni kitiems mokytis, gerbia kito darbuotojo nuomonę; vadovai dalijasi naujausia informacija apie technologijas, naujoves, kryptis. Nustatyta, kad ši istaiga atitinka Besimokančios organizacijos koncep-
\end{abstract}

ciją, tačiau nepakanka organizacijoje vien mokytis, būtina organizacijos valdymą orientuoti ị nuolatinị veiklos procesų tobulinimą, paremtą šiuolaikinio viešojo valdymo paradigma.

\section{Ivadas}

Inovacijos sveikatos sektoriuje skatina sveikatos priežiūros įstaigų vadovus ir darbuotojus nuolat mokytis ir igyti naujų žinių bei gebejimų. Auganti konkurencija tarp organizacijų motyvuoja jų vadovus iš naujo peržvelgti organizacijų veiklą ir skirti didesnį demesį darbuotojų mokymuisi [14]. Didejančių naujų technologijų proveržiai išryškina augantị išsilavinusių, kvalifikuotų, kompetentingų darbuotojų poreikị. Nuo turimos darbuotojų kvalifikacijos, žinių bei kompetencijos priklauso ir paslaugų kokybė bei sėkminga organizacijos veikla. Norédamos išlikti paklausiomis organizacijomis privalo nuolat tobulèti, mokytis, tapti kokybiškai naujomis - Besimokančiomis organizacijomis. Šiuolaikinis viešasis valdymas - tai žvelgimas ị priekị, galvojimas apie ateitį, kaip iš tradicinès, šiandieninès sveikatos priežiūros organizacijos tapti nuolat besimokančia, besivystančia, besikeičiančia, pacientų ir visuomenès poreikius atliepiančia organizacija. Lietuvoje dažniau praktikuojama investicija ị tuos darbuotojų ịgūdžius, kurių reikia dabartinėje jų veikloje, tačiau žvelgimas ị ateitị ugdant darbuotojus yra Besimokančios organizacijos bruožas, o šiuolaikinis viešas valdymas sudaro puikias galimybes būti sèkmingai dirbančiais. Svarbus yra pats požiūris į sveikatos priežiūros įstaigos valdymą. Ir šis požiūris turi būti integralus, apibrèžiantis nepriekaištingos veiklos formulę, kuri apjungia kokybės vadybos ir edukologijos, vadybos ir sveikatos mokslo teorijas.

Šiuolaikinio viešojo valdymo institucijos stengiasi sukurti lankstesnes organizacines struktūras. Organizacijos lankstumą jos supranta kaip gebejjimą veiksmingai derinti savo struktūrinę sąrangą ir funkcinę veiklą prie besikeičiančio viešojo sektoriaus ir visuomenès poreikio. Organizacinè kultūra ir jos suvokimas nuo organizacinių struktūrų ir procesų iki formų ir metodų parodo, kad galią ir kultūrą galima 
panaudoti kaip priemonę pasiekti aukštiems tikslams [1]. Mokymasis turi būti integrali naujos kokybès veiklos proceso igyvendinimo dalis. Visuotinè kokybès vadybos teorija rekomenduoja vadovaujantis naujomis žiniomis sistemingai analizuoti ir modifikuoti veiklos procesus. Besimokančios organizacijos nariai, besimokantys įvaldyti visuotinès kokybès metodus, turi stengtis panaudoti visus galimus organizacijos išteklius [19]. Organizacijos valdymo evoliucijos katalizatorius - inovatyvių valdymo idèjų formavimas, veiklos procesų reinventorizavimo formų ir metodų ịtvirtinimas viešojo sektoriaus valdymo praktikoje [20].

Mokslinejje literatūroje Besimokančiai organizacijai priskiriama daug bruožų, modelių, mokymosi metodų. Tyrimuose organizacijų vadovai deklaratyviai akcentuoja mokymosi naudą, efektyvumą, besimokančių darbuotojų palaikymą ir skatinimą, taip sudaromos palankios sąlygos profesiniam tobulejjimui. Vadovai Besimokančioje organizacijoje suvokiami kaip besimokantys lyderiai, strategai, planuotojai bei asmenybės. Anot Wick, Leon [31], lyderiai Besimokančioje organizacijoje geba ne tik nuolat mokytis, bet ir skleisti asmeninès lyderystès tikslus ir skatinti mokytis organizacijos darbuotojus. Hopkins ir kt. teigia [8], jog Besimokančios organizacijos vadovo kompetencijos yra svarbios, tačiau organizacijos kultūra ir ją palaikantys valdymo principai yra bendra kolektyvi veikla, visų organizacijos narių atsakomybè. Song ir kt. [27] teigia, jog „organizacijos, puoselëjančios Besimokančios organizacijos kultūrą, sèkmingai tobulina ir organizacinę veiklą".

Šiuolaikinio viešojo valdymo tyrimuose šiandien jau galima išskirti kai kuriuos rodiklius, kurie turi ịtakos efektyviai Besimokančios organizacijos sąlygoms ir veiksniams. Sisteminès analizès metodais teoretikai jau yra apibūdinę daug struktūrinių viešojo valdymo elementų, tokių kaip strateginis naujojo viešojo valdymo pobūdis, evoliucionuojantis iš naujosios viešosios vadybos, kaip esminès $\mathrm{XX}$ a. pabaigos viešojo valdymo teorinès doktrinos ir geriausios valdymo praktikos. Tarp kitų naujojo viešojo valdymo elementų reikia išskirti labiau humanistini, socialiai orientuotą visų valdymo lygiu pobūdi, telkiantị demesị ị kompleksinị socialiniu visuomenès problemų sprendimų pobūdi globalioje erdvejje, išaugusią socialinę visų rūšių ir lygių organizacijų atsakomybę realizuojant viešosios politikos, kaip esminès viešojo valdymo sudètinès dalies, programas ir projektus. Todèl išskirtinis dėmesys privalo būti skiriamas socialinių struktūrų vystymui, organizacinès elgsenos teorijos tobulinimui ir praktikos sklaidai, nes tik tokia viešojo valdymo plètotès trajektorija gali kur kas geriau spręsti pilietinès visuomenès formavimo sudètingumus bei realizuoti socialinių grupiu lūkesčius [22]. Todèl modernus viešasis valdymas, kaip sudètinga valdymo elementų visumos sistema, yra svarbi visos visuomenès, valstybės investicija generuojant strategines pokyčių valdymo užduotis viešojo sektoriaus organizacijose ir formuojant struktūrinị ir sisteminị pokyčių valdymo mechanizmų pobūdį. Svarbiausias viešojo valdymo pokyčių siekis visomis prasmèmis (institucinemis, ideologinėmis, socialinėmis, ekonominèmis, juridinėmis) yra nukreipti viešosios valdymo sferos veiklai optimizuoti, teikiant viešąsias paslaugas ir kuriant viešają tarpsektorinès ir tarpinstitucinès integracijos vertę, remiantis naujomis viešojo dalyvavimo formomis [21].

Šiuolaikinio viešojo valdymo elementais Besimokanti organizacija turètų remtis vykstančiais nuolatiniais pokyčiais, kad būtų ịgyvendintos ịvairios strategijos, ịvertintos perspektyvos, projektuojami strateginiai veiksmai, įvertinti vidiniai organizacijos pajëgumai, darbuotojų kompetencijos, siekiant kokybinių pokyčių i tikslą orientuotais procesais. Jei organizacija sparčių organizacinių pokyčių laikotarpiu nėra linkusi mokytis, tobulèti ir prisitaikyti, akivaizdu, nesugebès išlikti konkurencingomis sąlygomis. Sveikatos priežiūros isstaigos, teikiančios medicinines paslaugas, išgyvena pokyčiu laiką, jos turi spèti keistis su sparčiai besikeičiančiomis technologijomis, diegiamomis inovacijomis bei nuolat kintančiais visuomenès ir pacientų poreikiais. Ypač svarbu identifikuoti, kaip vyksta žinių kūimas ir informacijos perdavimas, ịgytos patirties refleksija ir veiklos perspektyvų apmąstymas siekiant organizacijos tikslų ir derinantis prie besikeičiančios aplinkos. Remiantis Karen E. Watkins ir Victoria J. Marsick [30] klausimynu - sudarytu pagal mokymosi lygius: individualų, grupinị, organizacinị - būtų galima vertinti Besimokančios organizacijos bruožų raišką šiuolaikinio viešojo valdymo kontekste.

Tikslui pasiekti numatyti uždaviniai: apžvelgti Besimokančios organizacijos koncepciją; pateikti pokyčių valdymo aspektus Besimokančioje organizacijoje; ištirti, kaip reiškiasi Besimokančios organizacijos bruožai mokymosi lygmenyse (individualiame, komandiniame, organizaciniame).

Tyrimo metodai - pirminių ir antrinių šaltinių duomenų analizè, metaanalizè, sisteminimas, teorinis modeliavimas, empirinis tyrimas, analizavimas ir interpretavimas.

Straipsni sudaro dvi dalys. Pirmoje dalyje analizuojama Besimokančios organizacijos koncepcija, bruožų raiška šiuolaikinio viešojo valdymo kontekste. Antroje dalyje esminis dèmesys skiriamas sveikatos priežiūros įstaigų darbuotojų nuostatoms ị mokymosi lygmenis.

Besimokančios organizacijos koncepcija, bruožų raiška. Nuolatinis, pastovus, svarbią reikšmę turintis organizacijos ir jos narių mokymasis bei tobulejimas tampa neįkainojamu turtu organizacijos veikloje. Vienas iš veiksnių, kuris skatina darbuotojų i̇sitraukimą ị darbą, yra Besimokančios organizacijos koncepcijos realizavimas, užtikrinantis 
nuolatinį mokymąsi ir tobulinimąsi, tiesiogiai susijusị su darbuotojo kasdieniniu darbu ir tobulejimu [16]. Organizacijos mokymasis grindžiamas sukauptos patirties ịprasminimu, gebejimu generuoti ir kaupti žinias, o pragmatiniu požiūriu - pasiekti strategini pranašumą prieš kitas organizacijas. Pastaruoju metu vis labiau nagrinejama Besimokanti organizacija (angl. The Learning Organization), o vykdant veiklą bei kartu mokantis, susiformavo ir Besimokančios organizacijos samprata. Besimokančios organizacijos yra tokios organizacijos, kuriose žmonès nuolat didina savo kompetenciją, siekdami rezultatų, kur laisvai plečiami komandiniai siekiai, ir kur žmonės be perstojo mokosi pamatyti visumą. Pagrindiniu Besimokančios organizacijos teorijos pagrindu laikomas mokymasis per veikimą, kai mokymasis vyksta iggyvendinant savo praktiką, ją apgalvojant, igyjant naujos patirties, ją valdant bei sukuriant naujas mokymosi galimybes [28]. L. Stoll ir D. Fink [29] teigia, kad Besimokančios organizacijos „kryptingai auga, gerai suvokia tikrovę ir padètį; kurios efektyviai, produktyviai ir lanksčiai planuoja, kurių sudètinè kultūros dalis yra nuolatinè plètra ir tobulejjimas". Fiol, Lyles [6], Kim [9], Murray, Donegan [15] teigia, jog bendrieji gebejjimai yra svarbūs Besimokančios organizacijos personalui, tačiau mokslininkai šiuos gebejjimus papildo Besimokančios organizacijos personalui būdingais specifiniais gebejjimais ir pateikia šias kompetencijų grupes: vadybinès kompetencijos (komunikacijos, lyderio, organizavimo); technologinès kompetencijos (technologijų naudojimo, aplinkos kūrimo); mokymosi kompetencijos (individualaus, komandinio, organizacinio mokymosi, žinių kūrimo); operacinès kompetencijos (finansų valdymo, finansų srautų sistemos išmanymo, procesų administravimo, greito reagavimo). Mokymasis organizacijai yra išlikimo, pajègumo stiprinimo būdas, igalinantis ją geriau keistis, t. y. susitvarkyti su pokyčiais, ir pasinaudoti naujomis galimybėmis. Mokslineje literatūroje pateikiama daug ir įvairių bruožų, charakteristikų, apibūdinančių Besimokančios organizacijos veiklos ypatybes: strategijos kūrimas, investicijos ị savo ateiti, bendradarbiavimas, aplinkos stebejimas, dèmesio koncentravimas ị problemų identifikavimą ir sprendimą, didelių informacijos srautų apdorojimas ir taikymas, reagavimas bei vidinių ir išorinių pokyčių nuspejjimas. Yra daugybẻ organizacijų, peržiūrinčių mokymo ir mokymosi procesą kaip būdą ígyti konkurencinị pranašumą [12]. Atsižvelgiant ị tai, su kokiais kompleksiniais pokyčiais ir iššūkiais susiduria viešosios sveikatos priežiūros ịstaigos, būtina nagrinèti kaip Besimokančią organizaciją šiuolaikinio viešojo valdymo kontekste.

Besimokančios organizacijos kūrimas nulemtas įvairių pokyčių ir organizacijos siekio mokytis. Kaip teigia Ghazali ir kt. [7], Besimokančioji organizacija - tai vieta, kurioje žmonès, norèdami išplèsti savo žinias ir įgūdžius, stipriai mokosi patys ir kolektyviai. Analizuojant Besimokančios organizacijos sampratą, galima įžvelgti ir kitą svarbų aspektą - mokymosi lygius, kur mokymasis apjungia individualų, gupių/komandų ir organizacijos lygmenis. Watkins, Marsick [30] išskiria individo-grupès/komandos-organizacijos lygmenyse vykstantị mokymąsi, orientuotą ị organizacijos tikslus, strategiją ir vizijos siekị. Mokymasis pagal šiuos lygmenis vyksta vienu metu. Individualus mokymasis vyksta kaskart, kai žmogus naudojasi informacija, eksperimentuoja ir įsivertina savo veiklos rezultatus, ieškodamas grį̌tamojo ryšio iš aplinkos. Grịžtamasis ryšys gali būti aktyvus (kažkas iš aplinkos įvertina jo pasiekimus) arba pasyvus. Komandinis mokymasis vyksta tuomet, kai du ar daugiau individų mokosi kartu veikdami. Šis mokymosi tipas gali įnešti naujus komandos narių atsakomybès būdus ir sąveikos tarp komandos narių aspektus (komunikaciją). Organizacinis mokymasis, kai organizacija išvysto sisteminị organizacijos žinių gavimo, naudojimo ir komunikavimo procesą [5]. Saugią paciento priežiūrą palengvina individualus profesinis mokymasis; tarpdisciplininis komandinis mokymasis ir sisteminis organizacinis mokymasis, apimantis modifikuotą konkretaus konteksto mokymąsi iš kelių grupių ir komandos narių sveikatos priežiūros organizacijoje. Organizacinis mokymasis asmens sveikatos priežiūros ịstaigoje yra būtinas mokymosi reikalavimų valdymui sudètinguose organizacijos struktūros lygmenyse, kuriose visi privalo turèti bendrąsias pagrindines žinias kartu su bendromis žiniomis apie vaidmenis ir atsakomybę, kad galètų vykdyti priskirtas funkcijas, bendrauti ir perduoti atitinkamos informacijos srautą ir kartu užtikrinti saugią paciento priežiūrą. Organizacinis mokymasis asmens sveikatos priežiūros ịstaigoje yra nuolatinis organizacinis reiškinys, vykstantis formaliojo ir savaiminio mokymosi metu, susietas su organizaciniais pokyčiais. Dẻl to organizaciniai pokyčiai atskleidžia organizacinį mokymąsi ir organizacinį mokymą, igyvendina naujas žinias ir praktiką organizacinių pokyčių kūrimui [25]. Organizacinis mokymasis laikomas būtinumu bet kuriai ịstaigai, nepriklausomai nuo kultūros ar veiklos srities, dèl to išauga išgyvenimo galimybès darbo rinkoje bei gebejjimas būti lanksčiam ir prisitaikyti [24]. Apibendrinant, galima teigti, kad Besimokanti organizacija - organizacija, kuri mokosi pati ir kartu skatina mokytis savo darbuotojus bei palaiko savo darbuotojų keitimąsi naujausia ir aktualiausia informacija, sukuria lanksčią organizaciją, kurios darbuotojai turi bendrą viziją ir lengvai priima naujas idejas bei prisitaiko prie pokyčių. Mokslinèje literatūroje galima rasti gana daug ir gana įvairių Besimokančios organizacijos bruožų, kurie yra būdingi būtent Besimokančiai organizacijai. Skirtingi mokslininkai koncentruojasi ị skirtingas detales, o ir patys bruožai yra išskiriami gana ịvairiai - vieni 
mokslininkai juos labai smulkiai detalizuoja, kiti jungia i stambesnes grupes, tačiau natūralu, kad vieno mokslininko išskirti Besimokančios organizacijos bruožai gali būti kito mokslininko išskirtų bruožų sudètine dalimi. Besimokanti organizacija pagal K.E. Watkins ir V.J. Marsick pasižymi šiais bruožais: 1) sudaroma galimybè nepertraukiamam mokymuisi; 2) skatinami tyrinejimai, eksperimentavimas bei dalijimasis žiniomis bei palaikomos pastangos kurti kultūrą, grịstą tyrinèjimu, grịžtamuoju ryšiu ir eksperimentavimu; 3) remiamas bendradarbiavimas ir komandinis mokymasis, kai tokioje organizacijoje siekiama sudaryti nuolatinio mokymosi galimybes visiems jos nariams, kurti bendrą mokymosi sistemą, kurioje vyktų dalijimasis mokymo(si) metodais bei žiniomis. Tokioje organizacijoje akcentuojamas bendradarbiavimas kaip galimybė mokytis, lankstumas; 4) sukurti bendrą mokymosi sistemą, kur organizacija turi užtikrinti tobulëjimą ịgalinančios aplinkos, mokymosi kultūros kūimą, kuomet visos veiklos organizacijoje traktuojamos kaip mokymosi procesas; 5) suteikti igaliojimus siekti kolektyvinès vizijos, kur darbuotojai yra suburiami bendram tikslui, jiems suteikiami igaliojimai ir visa tai didina motyvaciją mokytis; 6) prisitaikyti prie išorinės organizacijos aplinkos; 7) skatinti strateginę lyderystę - tai vadovų gebejjimas naudoti mokymąsi pokyčiams įgyvendinti bei sąlygų planingam ir sistemingam darbuotojų mokymuisi sudarymas. Vadovai turi kurti saugią ir mokymuisi palankią aplinką, kurioje žmonès gali eksperimentuoti, klysti, mokytis ir suprasti, ko iš jų tikimasi. Jei organizacinio mokymosi nepalaiko organizacijos lyderiai, mokymasis bus mažiau sèkmingas ir turès mažiau teigiamos ịtakos organizacijos rezultatams [4]. Vadovas tokioje organizacijoje - labiau lyderis, organizacinio dizaino kūrèjas, strategas, sugebantis numatyti tolimą ateitị ir net aplenkti lūkesčius, tam kompleksiškai panaudodamas visas savo žinias ir mąstymo gebėjimus, asmeninę gyvenimo patirtị.

Kompleksinis pokyčių valdymas viešojo sektoriaus besimokančioje organizacijoje. Kompleksinis pokyčių valdymas šiandien kelia itin aukštus reikalavimus viešojo sektoriaus Besimokančiu organizacijų kokybiniams parametrams, t. y. pokyčiu valdymo planavimui, veiklos vadybai, racionaliam išteklių valdymui, organizacinei lyderystei, sprendimų rengimui ir įgyvendinimui, nepertraukiamo mokymosi galimybei, žinių dalijimosi, bendro mokymosi sistemai bei kitiems kompleksinio pokyčių valdymo struktūriniams elementams. Todèl, analizuojant pokyčių valdymo proceso tobulinimo dekompoziciją, neišvengiamai susiduriama su organizacijų pasirengimo priimti pokyčius, inovatyvias idejas, formuoti palankią aplinką valdymo reformų ideologijai iggyvendinti vertinimu [3]. Vertinant Besimokančių organizacijų pasirengimą valdyti pokyčius, dominuoja kompleksinis požiūris ị organizacijų veiklos vadybą kaip tikslų, priemonių, formų ir metodų visumą. Galima konstatuoti, kad daugelyje valstybių viešojo sektoriaus institucijų veiklos vadyba, vertinimas ir rezultatų analizè tampa vis svarbesne viešojo sektoriaus institucijų veiklos sudedamaja dalimi, naudojama kur kas daugiau veiklos vadybos vertinimo kriterijų ir rodiklių, tarp kurių vyrauja kompleksinio pobūdžio bendrieji (tvarios pletros, funkcionalumo, legitimumo) ir specifiniai rodikliai, fiksuojantys specifinị instrumentini vadybos funkcijų realizavimo lygmeni, atsižvelgiant ị viešojo sektoriaus organizacijų veiklos tikslus, decentralizavimo lygmenị, funkcinę paskirtị ir kt. [2]. Viešojo sektoriaus organizacijoms, siekiančioms igyvendinti Besimokančios organizacijos koncepciją, reikia pertvarkyti savo organizacijos valdymo struktūrą [10]. Šiandieninis viešojo valdymo raidos etapas kelia itin didelius reikalavimus viešosios politikos sprendimų rengimo ir igyvendinimo dalyviams, tiesiogiai atsakingiems už sprendimų kokybę, îvairiomis partnerystès formomis susietais su sprendimų rezultatų kokybe suinteresuotais vartotojais, klientais, piliečiais kaip sprendimu procesų dalyviais. Globalių procesų poveikis suponuoja ir naujų viešųjų sprendimų būdų paieškos formų, metodologijų, procedūrų ịvairovę [23]. Tenka konstatuoti, kad įvairiose šalyse šiuolaikinio viešojo valdymo doktrina ịgauna specifinių bruožų globaliame viešojo valdymo reformų kontekste. Modernus valdymas šiuolaikiniame etape charakterizuojamas kaip naujų inovacinių veiklos vadybos modelių paieška ir diegimas, fokusuojant viešųų organizacijų veiklos procesus ị kompleksinių - integracinių struktūrų vietos ir vaidmens valdymo procesų kaitą.

Organizacijų lyderiai XXI a. pradžioje turi gebėti sutelkti organizacijos personalą strateginių užduočių, kuriant viešają vertę, realizavimui, mokèti racionaliai ir efektyviai naudotis išorès ekspertų ir ekspertizių sistemų galimybèmis formuojant palankią aplinką Besimokančiai organizacijai. Viešųų organizacijų vadovai ir aukščiausio lygio vadybininkai turi vadovautis moderniais kompleksinio pobūdžio imperatyvais: inovatyvumo ideologija, pokyčių ir reformų poreikio, būtinumo suvokimu, postmodernaus valdymo geriausios praktikos ir patirties panaudojimu savo organizacinèse struktūrose [18].

Efektyvesnę Besimokančios organizacijos veiklą sąlygotų sistemingas valdymas [17]. Tyrimai rodo, kad, siekiant efektyvesnio viešojo valdymo, itin svarbi pačių Besimokančios organizacijos vadovų ir darbuotojų aktyvi pozicija ir netgi agresyvios pastangos, ịveikiant esamus trūkumus ir kliūtis. Plačiaja prasme efektyvus administravimas yra pozityvios administratorių veiklos produktas, gebejjimų realizavimas, pasitikejjimas savo jègomis, t.y. "can-do" požiūris.

Tyrimo tikslas: atskleisti Besimokančios organizacijos bruožų raišką šiuolaikinio viešojo valdymo kontekste. 


\section{Tyrimo metodika}

Tyrimo metodologinį pagrindą sudaro K.E. Watkins ir V.J. Marsick [30] aprašytas Besimokančios organizacijos modelis, kuris teigia, kad mokymasis organizacijose turi vykti individo, komandos ir organizacijos lygmenimis. Besimokančios organizacijos metmenų klausimynas (angl. Dimensions of the Learning Organization Questionnaire) sudarytas iš K.E. Watkins ir V.J. Marsick tyrinejjimų ir matuoja svarbius poslinkius organizacijos klimate, kultūroje, sistemose bei struktūroje. Klausimyno patikimumas buvo įrodytas daugeliu tyrimų, kurie buvo atlikti ịvairiose pasaulio šalyse ir skirtingose veiklos sferose. Besimokančios organizacijos bruožų raiškos pagal dimensijas klausimynas sudarytas iš 62 teiginių, kurie ịvertinti Likerto (Likert) 6 rangų skalèje nuo 1 (niekada) iki 6 (visada). Pagal teorinį Besimokančios organizacijos modeli parengtas empirinis Besimokančios organizacijos tyrimo instrumentas - standartizuota anketa.

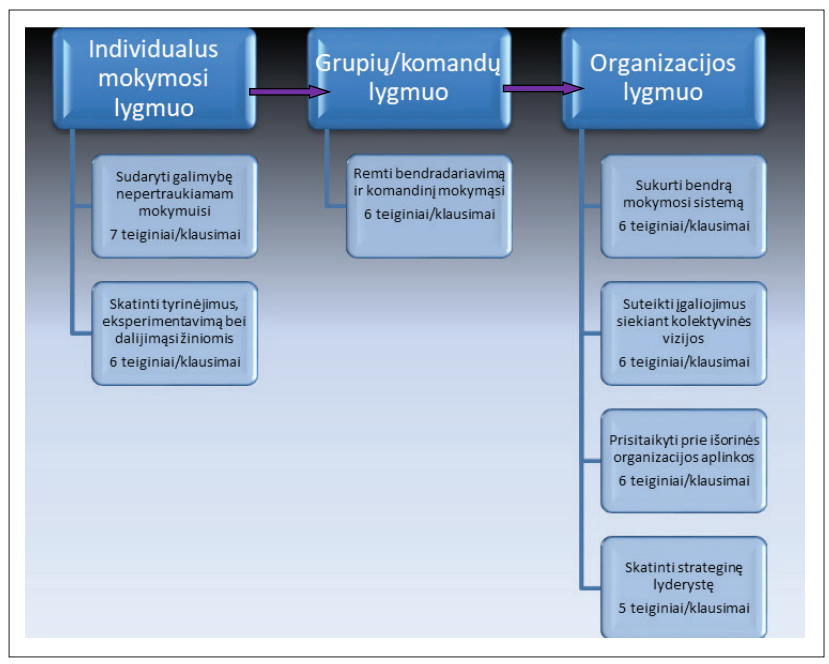

1 pav. Besimokančios organizacijos bruožų raiškos modelis. Sudarytas autorių pagal K.E. Watkins ir V.J. Marsick (2003)

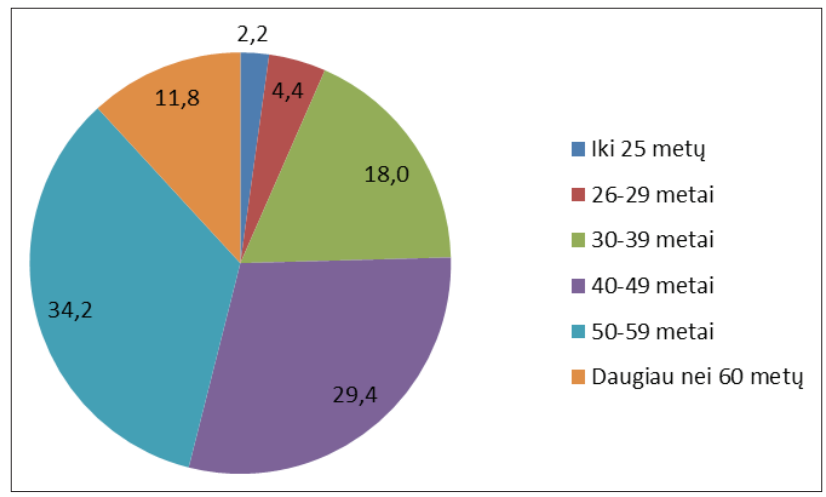

2 pav. Respondentų pasiskirstymas pagal amžių (proc.)
Sudarytas Besimokančios organizacijos bruožų raiškos modelis (1 pav.). I sudarytą klausimyną įtraukti 48 teiginiai, kitų buvo atsisakyta, nes šiai ambulatorinei asmens sveikatos priežiūros įstaigos organizacijos kultūrai tai neaktualu. Faktorinès analizès būdu klausimynas tikrintas pagal teiginių pasiskirstymą septyniose potemèse ir trijuose diagnostiniuose blokuose respondentų nuostatoms organizacijoje įvertinti individualų, grupių/komandos ir organizacinį mokymosi lygmenị. Tyrimas buvo atliekamas $2017 \mathrm{~m}$. sausio - kovo mèn. pasirinktoje ambulatorinėje asmens sveikatos priežiūros įstaigoje.

Tyrimo imtis. Šiame darbe tikslinè populiacija - ambulatorinès asmens sveikatos priežiūros įstaigos darbuotojai. Tyrimo erdvé - viena ambulatorinè asmens sveikatos priežiūros ịstaiga. Imties struktūros nustatymas. Pasirinkti darbuotojai iš įvairių įstaigos padalinių, ivvairių pareigybių, siekiant aprèpti kuo platesnę tyrimo geografiją, kad duomenys būtų ịvairesni. Imties didumo parinkimas. Empiriniam tyrimui atlikti suformuluota lizdinè imtis. Visa populiacija pagal tam tikrą požymị buvo suskirstoma ị lizdus (klasterius). Iš visų lizdų aibès paprastosios atsitiktinès imties būdu atrinktos dalys. I̦ imtị pakliuvo visi atrinktųjų lizdų elementai. Kadangi tiriama visos ịstaigos Besimokančios organizacijos bruožų raiška praktinèje situacijoje, o įstaigoje yra 952 darbuotojai, todèl vieno padalinio darbuotojai atitinka vieną lizdą. Atsitiktinai buvo parinkta dešimt padalinių, o tai tikimybinè imtis ir rezultatai apibendrinti visai populiacijai (organizacijai).

Duomenų analizè. Apklausos duomenys analizuoti statistine programa SPSS (angl. - Statistical Package for the Social Sciences), pateikti naudojant MS Excel programą. Lyginant imtis pagal tai, kaip respondentai vertino teiginius, naudota atsakymų (kintamujų reikšmių) aritmetinių vidurkių (angl. - Mean) reikšmès. Vienos imties vidurkių palyginimui naudotas One-Sample T Testas. Tikrinant statistines hipotezes naudotas 0,05 reikšmingumo lygmuo. Kai tikimybè - $p$ $<0,05$ - vidurkių skirtumai statistiškai reikšmingi, kai $p>$ 0,05 - statistiškai nereikšmingi.

Respondentų charakteristikos. Tyrime dalyvavo 228 respondentai, iš kurių absoliučią daugumą (93 proc.) sudarè moterys. Respondentai pateikè atsakymus apie savo amžių naudodami klausimyne pateiktas 6-ias amžiaus kategorijas. 
Respondentai iki 25 m. ir 26-29 m. sudaro mažiausią imties dali - atitinkamai 2,2 proc. ir 4,4 proc., Beveik kas dešimtas respondentas (11,8 proc.) vyresnis nei 60 metų. Kas penktas respondentas (18 proc.) priklauso $30-39 \mathrm{~m}$. amžiaus kategorijai, 40-49 m. respondentai sudaro 29,4 proc., o didžiausią imties dali (34,3 proc.) sudaro 50-59 metų respondentai (2 pav.).

Padalinių vadovų dalis tarp visų apklaustujų 7,9 proc., gydytojų - 30,3 proc., slaugytojų $-46,9$ proc. (jos sudarè kone pusę apklaustujų ), o kitų pareigų darbuotojų (kineziterapeutų, ergoterapeutų, medicinos psichologų, medicinos biologu, laborantų) $-14,9$ proc.

\section{Tyrimo rezultatai}

Atlikus Besimokančios organizacijos bruožų raiškos analizę individualiame, grupių/komandų bei organizacijos lygmenyje, nustatyta, kad aukščiausiai įvertintas mokymasis organizacijos lygmenyje (bendras vertinimo vidurkis - 3,81 balo), kiek žemiau - mokymasis grupių/komandų lygmenyje ( 3,7 balo) ir žemiausiai - mokymasis individualiame lygmenyje (3,63 balo). Mokymosi organizacijos lygmenyje bendras vidurkis yra aukštesnis ir statistiškai reikšmingai skiriasi (One- Sample Test, $T$ Test rezultatas $p=0,004 ; p<0,05)$ nuo mokymosi individualiame lygmenyje bendro vidurkio (3 pav.).

Besimokančios organizacijos bruožų raiškos vertinimas. Individualaus mokymosi lygmens bendras vertinimo vidurkis $-3,63$ balo. Šios dimensijos bruožų raiškai organizacijoje identifikuoti pasitelkta 13 diagnostinių teiginių, kurie suskirstyti ị dvi potemes: Sudaryti galimybę nepertraukiamam mokymuisi ir Skatinti tyrinèjimus, eksperimentavimą bei dalijimąsi žiniomis. Nagrinejjant Besimokančios organizacijos bruožų raišką atskirose potemèse, nustatyta, jog potemejje Sudaryti galimybę nepertraukiamam mokymuisi (4 pav.) geriausiai vertinama ,darbuotojai padeda vieni kitiems mokytis" ( 3 teiginys, vidurkis 4,26 ), antroje vietoje - „darbuotojai atvirai aptaria klaidas, kad iš jų vèliau būtų galima pasimokyti“" (1 teiginys, vidurkis 3,96 ) bei trečioje vietoje - ,darbuotojai ị iškilusias problemas žiūri kaip ị galimybę pasimokyti“" (6 teiginys, vidurkis 3,78). Šių teiginių vertinimo vidurkiai statistiškai reikšmingai skiriasi (One- Sample Test, T Test rezultatas (tarp 3-io ir 1 -o teiginių) $p=0,001 ; 1: 6 p=0,034,6: 2 p=0,035)$.

Prasčiausiai šioje potemèje buvo vertintas tei-

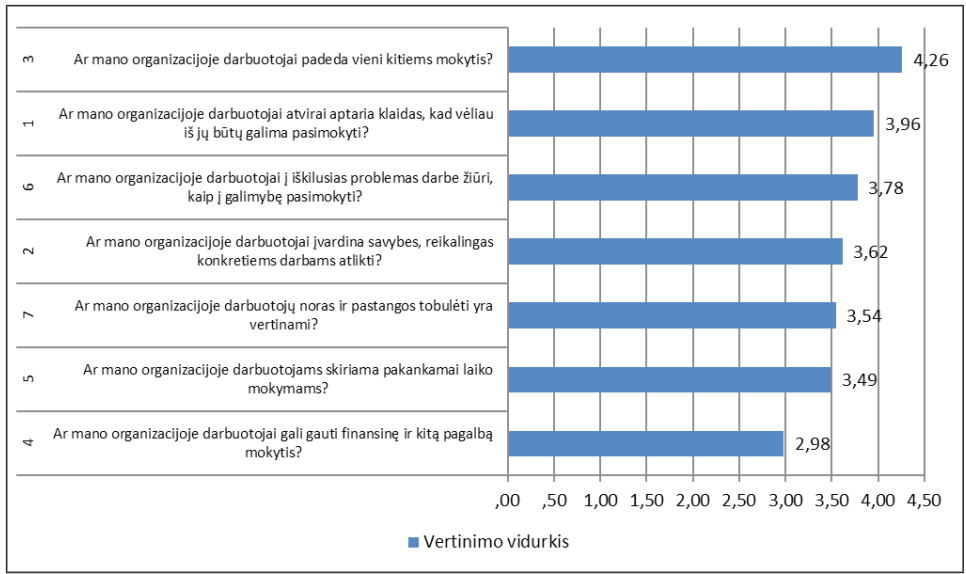

4 pav. Individualaus mokymosi lygmens potemės „Sudaryti galimybę nepertraukiamam mokymuisi“" diagnostinių teiginių vertinimo vidurkiai

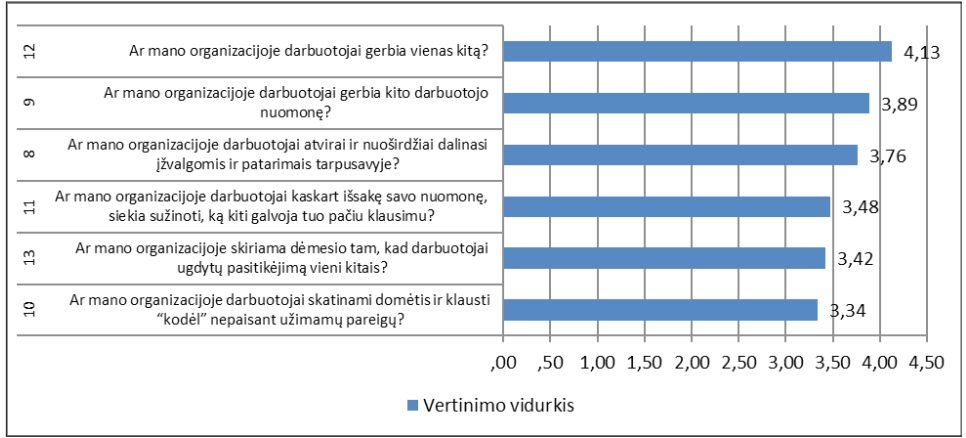

5 pav. Individualaus mokymosi lygmens potemès ,Skatinti tyrinèjimus, eksperimentavimą bei dalijimąsi“ žiniomis diagnostinių teiginių vertinimo vidurkiai

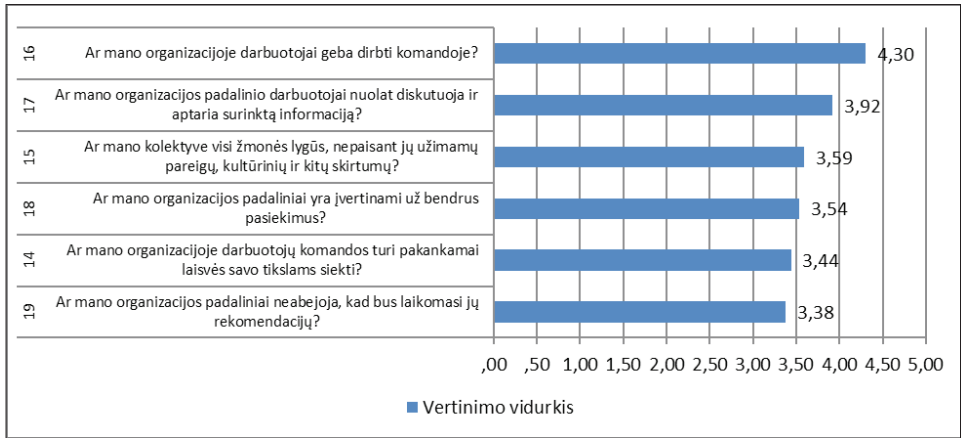

6 pav. Grupių/ komandų lygmens „Remti bendradarbiavimą ir komandinị mokymąsi“ diagnostinių teiginių vertinimo vidurkiai

ginys „darbuotojai gali gauti finansinę ir kitą pagalbą mokytis“ (4 teiginys, vidurkis 2,98) (One-Sample T Test, rezultatas 5:4 p=0,000). Kitų teiginių vidurkiai statistiškai reikšmingai nesiskiria (4 pav.).

Besimokančios organizacijos bruožų raiškos potemejje Skatinti tyrinèjimus, eksperimentavimą bei dalijimąsi žiniomis (5 pav.) geriausiai vertinama „darbuotojai gerbia vienas kitą“ (12 teiginys, vidurkis 4,13), 


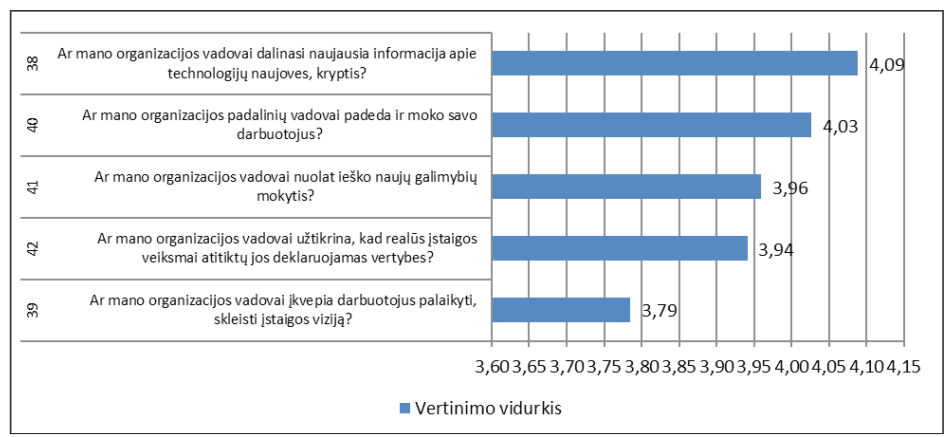

7 pav. Organizacijos lygmens potemės „Susikurti bendrą mokymosi sistemą“ diagnostinių teiginių vertinimo vidurkiai

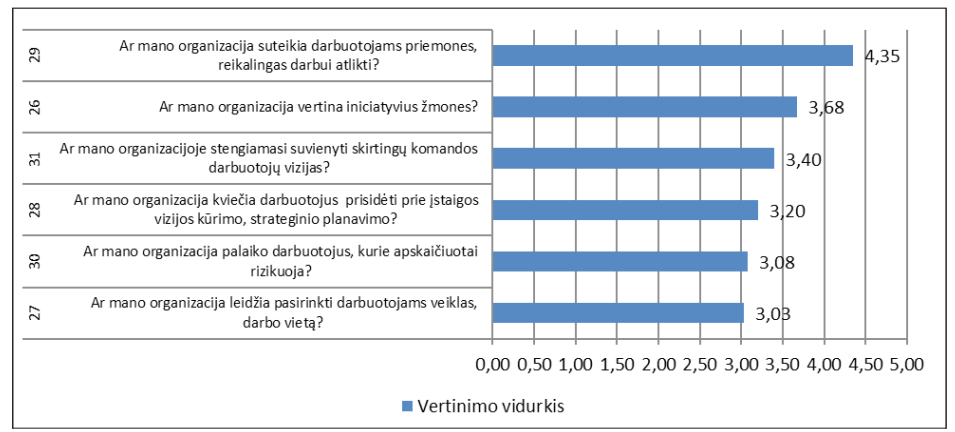

8 pav. Organizacijos lygmens potemès „Suteikti igaliojimus siekiant kolektyvinès vizijos" diagnostinių teiginių vertinimo vidurkiai

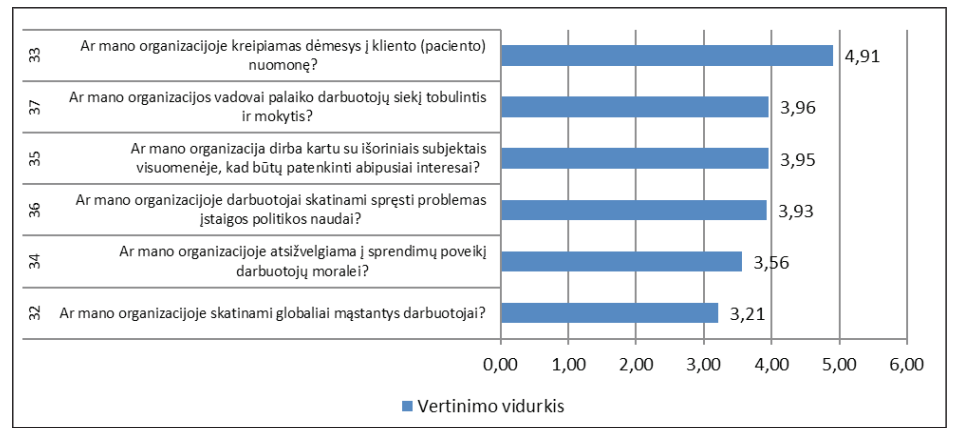

9 pav. Organizacijos lygmens potemės „Prisitaikyti prie išorinės organizacijos aplinkos" diagnostinių teiginių vertinimo vidurkiai

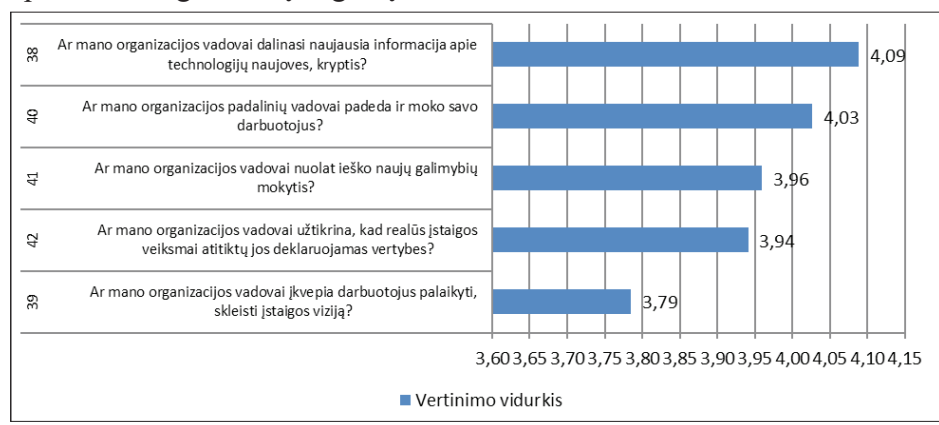

10 pav. Organizacijos lygmens potemės „Skatinti strateginę lyderystę“ diagnostinių teiginių vertinimo vidurkiai kiek žemiau - „darbuotojai gerbia kito darbuotojo nuomonę“ (9 teiginys, vidurkis 3,89) ir „darbuotojai nuoširdžiai dalinasi įžvalgomis ir patarimais tarpusavyje“ (8 teiginys, vidurkis 3,76 ). Šių teiginių vertinimo vidurkiai statistiškai reikšmingai skiriasi (One Sample Test, T-test rezultatas 12:9 p=0,004, $12: 8 \mathrm{p}=0.000$ ) ir žemiausiai - „darbuotojai, kaskart išsakę savo nuomonę, siekia sužinoti, ką kiti galvoja tuo pačiu klausimu“ (11 teiginys, vidurkis 3,48$)$, ,organizacijoje skiriama demesio tam, kad darbuotojai ugdytų pasitikèjimą vieni kitais“ (13 teiginys, vidurkis 3,42) ir „darbuotojai skatinami domètis ir klausti „kodèl“" nepaisant užimamų pareigų“(10 teiginys, vidurkis 3,34). (One-Sample T Test, T-test rezultatas $8: 11 \mathrm{p}=0,000,11: 13 \mathrm{p}=0,471,13: 10 \mathrm{p}=0,380)$.

Mokymasis grupiu/komandu lygmenyje. Mokymosi grupiu/ komandų lygmenyje bendras vertinimo vidurkis $-3,70$ balo. Šios dimensijos raiškai organizacijoje identifikuoti pasitelkta 6 diagnostiniai teiginiai. Nagrinejjant Besimokančios organizacijos bruožų raišką grupių/komandų lygmenyje - remti bendradarbiavimą ir komandinị mokymąsi (6 pav.), nustatyta, kad aukščiausiu vidurkiu įvertintas teiginys ,darbuotojai geba dirbti komandoje” (16 teiginys, vidurkis 4,3), antroje pozicijoje - „mano padalinio darbuotojai nuolat diskutuoja ir aptaria surinktą informaciją“" (vidurkis $(3,92)$. Šių teiginių vertinimo vidurkiai statistiškai reikšmingai skiriasi (One-Sample T Test, T-test rezultatas $\mathrm{p}=0,000$ ). Likusių teiginių $(15,18,14$ ir 19) vertinimo vidurkiai reikšmingai nesiskiria.

Mokymasis organizacijos lygmenyje. Atlikta duomenų analizè rodo, jog mokymosi organizacijos lygmenyje bendras vertinimo vidurkis $-3,81$ balo. Šios dimensijos raiškai organizacijoje identifikuoti pasitelkta 23 diagnostiniai teiginiai, kurie suskirstyti i keturias potemes: Sukurti bendrą mokymosi sistemą; Suteikti igaliojimus siekiant kolektyvinès vizijos; Prisitaikyti prie išorinès organizacijos aplinkos; Skatinti strateginę lyderystę. Nagrinėjant Besimokančios organizacijos bruožų raišką atskirose potemèse, nustatyta, jog potemèje Sukurti bendrą mokymosi sistemą geriausiai vertinama du teiginiai ,organizacijoje tobulinimosi galimybès ir informacija yra prieinama visiems darbuotojams" (24 teiginys, vidurkis 4,09) ir „darbuotojai gali gauti reikiamos informacijos bet kuriuo metu, greitai ir lengvai“" (21 teiginys, vidurkis 3,96). Šių teiginių vertinimo vidurkiai statistiškai reikšmingai neskiria (One Sample Test, T-test rezultatas 24:21 p=0,116). 


\section{4}

Prasčiausiai buvo vertintas teiginys „organizacija ịvertina mokymosi laiką ir sąnaudas bei gautus mokymosi rezultatus“" (25 teiginys, vidurkis 3,45) (One- Sample T Test, T-test rezultatas 20:25 $\mathrm{p}=0,000)$ (7 pav.).

Potemėje Suteikti igaliojimus siekiant kolektyvinès vizijos geriausiai vertinama ,organizacija suteikia darbuotojams priemones, reikalingas darbui atlikti“ (29 teiginys, vidurkis $4,35)$, antroje vietoje - „organizacija vertina iniciatyvius žmones“" (26 teiginys, vidurkis 3,68) ir trečioje - ,organizacijoje stengiamasi suvienyti skirtingų komandos darbuotojų vizijas" (31 teiginys, vidurkis 3,40$)$. Šių teiginiu vertinimo vidurkiai statistiškai reikšmingai skiriasi (One-Sample T Test, T-test rezultatas 29: $26 \mathrm{p}=0,000,26: 31 \mathrm{p}=0,003,31: 28$ $\mathrm{p}=0,022)$. Likusių diagnostinių teiginių vidurkiai statistiškai reikšmingai nesiskiria (8 pav.).

Potemėje Prisitaikyti prie išorinès organizacijos aplinkos (9 pav.) geriausiai ịvertintas teiginys „organizacijoje kreipiamas dèmesys ị kliento (paciento) nuomonę" (33 teiginys, vidurkis 4,91). Jis reikšmingai skiriasi nuo pagal vidurkị žemiau išsidèsčiusių teiginių (One Sample Test, T-test rezultatas 33:37 p=0,000). Žemiausiais vidurkiais įvertinti šios potemès teiginiai priešpaskutinèje vietoje - „organizacijoje atsižvelgiama ị sprendimų poveikị darbuotojų moralei“ (34 teiginys, vidurkis 3,56 ) ir paskutineje vietoje - „organizacijoje skatinami globaliai mąstantys darbuotojai““ (32 teiginys, vidurkis 3,21). Šių teiginių vidurkiai reikšmingai skiriasi ir skiriasi nuo aukščiau už juos išsidèsčiusių teiginių (One-Sample Test, T-test rezultatas 34:32 p=0,000, 34:36 $\mathrm{p}=0,000)$.

Potemėje Skatinti strateginę lyderystę vertinimo vidurkiai statistiškai reikšmingai nesiskiria (One- Sample Test, T-test rezultatas $38: 40 \mathrm{p}=0,534,40: 41 \mathrm{p}=0,462,41: 42 \mathrm{p}=0,829$, $42: 39 \mathrm{p}=0,081)(10 \mathrm{pav}$.$) .$

Nustatyta, kad organizacinis mokymasis laikomas būtinu organizacijos gebejjimu lanksčiai reaguoti ị vidinius ir išorinius pokyčius šiuolaikinès Besimokančios organizacijos kontekste.

\section{Išvados}

1. Atlikus mokslinès literatūros analizę apie Besimokančios organizacijos koncepciją galima teigti, kad Besimokanti organizacija viešojo valdymo kontekste - tai organizacija, kuri mokosi individualiame, grupių/komandų, organizacijos lygmenyse. Tokia organizacija mokosi pati ir kartu skatina mokytis savo darbuotojus bei palaiko darbuotojų keitimąsi naujausia ir aktualiausia informacija, sukuria lanksčią organizaciją, kurios darbuotojai turi bendrą viziją, didelị dèmesị skiria vadybinèms ir technologinèms inovacijoms, lengvai priima naujas idèjas bei prisitaiko prie pokyčių, padedančių organizacijai tapti inovatyvia, konkurencinga. Galima kons- tatuoti, kad daugelyje viešojo sektoriaus organizacijų veiklos vadyba, vertinimas ir rezultatų analize tampa vis svarbesne viešojo sektoriaus institucijų veiklos sudedamaja dalimi. Viešojo sektoriaus organizacijoms, siekiančioms įgyvendinti Besimokančios organizacijos koncepciją, reikia pertvarkyti savo organizacijos valdymo struktūrą. Viešųų organizacijų vadovai ir aukščiausio lygio vadybininkai turi vadovautis moderniais kompleksinio pobūdžio imperatyvais: inovatyvumo ideologija, pokyčių ir reformų poreikio, būtinumo suvokimu, postmodernaus valdymo geriausios praktikos ir patirties panaudojimu savo organizacinėse struktūrose, o efektyvesnę Besimokančios organizacijos veiklą sąlygotų sistemingas valdymas.

2. Tyrimai rodo, kad efektyvus šiuolaikinis viešasis valdymas itin svarbus Besimokančios organizacijos vadovų ir darbuotojų pozicijai bei pastangoms priimti ir valdyti pokyčius, kompleksiškai pertvarkant organizacijos valdymo struktūrą. Plačiaja prasme efektyvus valdymas yra pozityvios veiklos produktas, gebejjimų realizavimas ir pasitikejjimas savo jègomis.

3. Atlikus Besimokančios organizacijos kaip mokymosi aplinkos bruožų tyrimą, nustatyta, kad:

- ambulatorinès asmens sveikatos priežiūros ịstaigos kritinis darbuotojų mokymosi taškas yra nepakankamas finansinės ir kitos pagalbos skyrimas visų pareigybių specialistams;

- aukščiausiai ịvertintas mokymasis organizaciniame lygmenyje, toliau - grupių/komandų, žemiausiai - individualiame lygmenyje;

- didžiausia ambulatorinès asmens sveikatos priežiūros organizacijos stiprybé - dèmesio kreipimas ị kliento (paciento) nuomonę;

- organizacija suteikia darbuotojams priemones, reikalingas darbui atlikti;

- darbuotojai geba dirbti komandoje, padeda vieni kitiems mokytis, gerbia kito darbuotojo nuomonę;

- vadovai dalinasi naujausia informacija apie technologijas, naujoves.

Galime teigti, kad tirtos ambulatorinès asmens sveikatos priežiūros įstaigos kryptingas organizacinis mokymasis sąlygoja tobulejimą, didina konkurencinị pranašumą ir leidžia prisitaikyti prie pokyčių bei igalina juos valdyti, o kiekvienas jos darbuotojas gali realizuoti save. Atlikti tyrimai patvirtina, kad tyrime dalyvavusi organizacija atitinka Besimokančios organizacijos koncepciją, o organizacijos valdymas orientuotas ị nuolatinį veiklos procesų tobulinimą, paremtą šiuolaikinio viešojo valdymo paradigma.

\section{Literatūra}

1. Bolman LG, Deal, Deal TE. Reframing organizations. San Francisco: Jessey Bass Publishers 2017. 
https://doi.org/10.1002/9781119281856

2. Bouckaert G, Halligan J. Managing performance. international comparisons. London: Routledge 2008.

3. Chlivickas E. Viešojo sektoriaus žmogiškujų išteklių potencialo plètra. Public Administration, 2012; 2(34):16-26.

4. Dačiulytė R. Žmogiškųjų išteklių vystymo aspektai Lietuvos savivaldybėse // Viešoji politika ir administravimas, 2011; 10:4.

5. Dixon N. Organizational learning. Otawa; conference Board of Canada Report 1993; 11-93.

6. Fiol CM, Lyles MA. Organizational learning. Academy of Management Review 1985; 10(4):803-813.

7. Ghazali MFIM, Kassim NA, Khalib LH, Jaafar MN, Idris MA. Conceptualizing Learning Organization towards Sustaining Learning Organization's Performan. Journal International Journal of Academic Research in Business and Social Sciences 2015; $5(1) ; 147-154$

8. Hopkins D, Ainscow M, West M. Kaita ir mokyklos tobulinimas. Vilnius. Tyto alba, 1998.

9. Ji Hoon Song, Doo Hun Lim, In Gu Kang, Woocheol Kim, Team Kim D. The link between individual and organizational learning. Sloan Management Review. No. Fall 1993; 37-50.

10. Klemsdal L, From bureaucracy to learning organization: critical minimum specification design as space for sensemaking, Systemic Practice and Action Research 2013; 26:39-52.

https://doi.org/10.1007/s11213-012-9267-3

11. Lim DH, Song JH, Yoon SW. Trends and issues in integrating knowledge management and organizational learning for workplace performance improvement. In Chalofsky NE, Rocco TS, Morris ML. (Eds.) Handbook of human resource development 2014; 369-385. Hoboken, NJ: Wiley. https://doi.org/10.1002/9781118839881.ch22

12. Mahapatra P, Kumar Kar A. From Organizational Learning to the Learning Organization: A Paradigm Shift. IJARIIE 2016; 2(6).

13. MarsickVJ,Watkins KE. Demonstrating the Valueofan Organization's Learning Culture: the dimensions of the Learning Organization Questionnaire. Advancesin Developing Human Resources May 2003; 5(2):132-151. https://doi.org/10.1177/1523422303005002002

14. Merkys L., Šlapšienė O., Personalo mokymas(is) - besimokančios organizacijos kūrimo(si) prielaida. Studijos šiuolaikinèje visuomeneje, 2013; 4(1):43-54.

15. Murray P, Donegan K. Empirical linkages between firm competencies ant organisational learning. The Learning Organization 2003; 10(1):51-62. https://doi.org/10.1108/09696470310457496

16. Norashikin H, Nurain Anis AR \& Muhamad Khalil O. Learning Organization and work engagement: an empirical evidence of a higher Learning Institution in Malaysia. Journal Information Management and Business Review 2017; 9(1); 17-22. https://doi.org/10.22610/imbr.v9i1.1592
17. Osborne D, Gaebler T. Reinventing Government. How the entrepreneurial spirit is transforming the public sector: reading mass, Addison. VVesley 1992; 7-8.

18. Osborne St, Brown L. Innovation, Public Policy and Public Service Delivery in the UK. Public Administration Review 2011; 65(6):713-727.

19. Puškorius, Raipa. Teoriniai viešojo sektoriaus veiklos modernizavimo aspektai. Viešoji politika ir administravimas, 2002; 2.

20. Raipa A. Viešojo valdymo evoliucija XXI amžiuje: priežastys, struktūra, poveikis, 2014.

21. Raipa A., Bartkus E. V. Modernus viešasis valdymas: pokyčiai ir nauji metodologiniai aspektai. Viešasis administravimas, 2013; 3(39):28-38.

22. Raipa A., Dūda M. Naujasis viešasis valdymas: viešojo ir privataus sektoriu partnerystė. Viešasis administravimas, 2011; 2(30):17-26.

23. Raipa A., Buškevičiūtė J. Piliečių dalyvavimas priimant sprendimus: naujojo viešojo valdymo kontekstas. Viešasis administravimas 2011; 2(30):27-35

24. Palos R, Stancovici VV. Learning in organization. The Learning Organization 2016; 23(1):2-22 https://doi.org/10.1108/TLO-01-2015-0001

25. Ratnapalan S, Uleryk E. Organizational Learning in Health Care Organizations. Systems 2014; 2:24-33. https://doi.org/10.3390/systems2010024

26. Schein EH. Organizational culture and Leadership. (3rd edition). New York: Wiley Publishers 2004.

27. Song JH. ir kt. Team performance in learning organizations: mediating effect of employee engagement, The Learning Organization 2014; 21(5):290-309. https://doi.org/10.1108/TLO-07-2012-0049

28. Senge PM. The fifth discipline: the art and practice of the Learning Organization. New York : Doubleday/ Currency 1990.

29. Stoll L, Fink D. Keičiame mokyklą. - Vilnius. Margi raštai, 1998.

30. Watkins KE \& Marsick VJ. Sculpting the learning organization. San Francisco: Jossey-Bass 2003.

31. Wick CW, Leon LS. The learning edge: how smart managers and smart companies stay ahead. NY: McGraw-Hill 1993.

\section{LEARNING ORGANIZATION IN THE CONTEXT OF THE MODERN PUBLIC ADMINISTRATION}

\section{Skrickienė, D. Čepuraitė, K. Štaras}

Key words: Learning organization, modern public management, change management, public sector.

Summary

According to Karen E. Watkins and Victoria J. Marsick's questionnaire (1993) which is based on the levels of learning: individual, group, and organizational, in order to assess the expression of the characteristics of the Learning Organization in the context of contemporary public administration, the study was conducted in 2016. In October - December, 228 employees were interviewed at 
an outpatient health care institution. In many public sector organizations, the management, evaluation and performance analysis of activities are becoming an increasingly important component of the activities of public sector institutions. Public sector organizations seeking to implement the concept of a learning organization need to reorganize their organization's governance structure. An outpatient personal health care institution's critical point in the training of employees is the inadequate allocation of financial and other assistance to all jobseekers. The highest rated organizational learning levels were found, hereinafter referred to as groups / teams, and at the lowest level on an individual level. We can say that goal-oriented organizational learning in an out-patient health care institution determines the development, increases the competitive advantage and allows adaptation to change and management, and gives each employee an opportunity for self-realization. The study found that the largest strength of an outpatient person"s health care organization was focusing on the client's (patient's) opinion; The organization provides employees with the tools necessary to carry out their work; employees are able to work in a team, help each other learn, respect the opinion of another employee; managers share the latest information on technologies, innovations, trends. We can say that this institution seeks to become a learning organization, but is not enough to learn alone; it is imperative that the organization's management should be oriented towards continuous improvement of the processes and based on the paradigm of contemporary public management. Purpose of the research: To reveal the expression of the characteristics of the learning organization in the context of contemporary public administration.

Correspondence to: laima.skrickiene@pylimas.lt

Gauta 2018-02-02 